\title{
Neurotrophins Induce Death of Hippocampal Neurons via the p75 Receptor
}

\author{
Wilma J. Friedman \\ Department of Pathology, Taub Institute for the Study of Alzheimer's Disease and the Aging Brain, and the Center for \\ Neurobiology and Behavior, Columbia University College of Physicians and Surgeons, New York, New York 10032
}

\begin{abstract}
Nerve growth factor (NGF) and related neurotrophins influence neuronal survival and differentiation via interactions with the trk family of receptors. Recent studies have demonstrated that neurotrophins may also induce cell death via the p75 receptor. The importance and generality of neurotrophin-induced death in the brain have not been defined but may play a critical role during development and in disease-associated neuronal death. Here we demonstrate for the first time that all four members of the neurotrophin family directly elicit the death of hippocampal neurons via the p75 receptor. The hippocampus is a complex structure
\end{abstract}

with many different neuronal subpopulations, and signals that influence neuronal death during development may have a critical impact on the mature function of this structure. In these studies we show that each neurotrophin causes the death of hippocampal neurons expressing p75 but lacking the cognate trk receptor. Neurotrophin-induced neuronal death is mediated by activation of Jun kinase. These studies demonstrate that neurotrophins can regulate death as well as survival of CNS neurons.

Key words: neurotrophins; NGF; neurotrophin receptors; $p 75$; apoptosis; Jun kinase
The neurotrophins nerve growth factor (NGF), brain-derived neurotrophic factor (BDNF), neurotrophin 3 (NT3), and NT4 have been shown to play several important roles in the development of peripheral and central neurons. One critical role is to support the survival of many neuronal populations during the period of developmental cell death (Oppenheim et al., 1992). The survival effects of neurotrophins are mediated via the trk family of receptors: TrkA, TrkB, and TrkC. NGF binds specifically to TrkA (Hempstead et al., 1991; Kaplan et al., 1991; Klein et al., 1991a), TrkB is a receptor for BDNF and NT4 (Klein et al., 1991b; Ip et al., 1992), and TrkC binds NT3 (Lamballe et al., 1991). In addition, all neurotrophins bind to a common receptor, p75, that can modify the binding and function of neurotrophins when coexpressed with trk receptors (Lee et al., 1994; Rydén et al., 1997). Recent studies have shown that interaction of NGF with the p75 receptor in the absence of trk signaling can cause cell death (Rabizadeh and Bredesen, 1994; Casaccia-Bonnefil et al., 1996; Frade et al., 1996); however the importance of this phenomenon for the development of CNS neurons has not been determined. The $\mathrm{p} 75$ receptor is more widely expressed in the CNS during development than in the adult (Yan and Johnson, 1988), suggesting that this receptor may have a special role during development. In particular, expression of p75 may help target neurons for developmental cell death in the CNS. These studies demonstrate that all four neurotrophins directly elicit the death of developing hippocampal neurons. In the hippocampus, factors that influence developmental death may have important impact on the mature function of this structure, which is critically involved in learning and memory.

In the adult CNS, neurons of the hippocampus produce all four neurotrophins, which serve as target-derived factors for afferent neurons from the basal forebrain (Hefti et al., 1984; Alderson et al., 1990; Friedman et al., 1993; Chen et al., 1997), locus coeruleus

Received Feb. 18, 2000; revised June 13, 2000; accepted June 16, 2000.

This work was supported by a grant from the National Institute of Neurological Disorders and Stroke. I am grateful to Genentech for providing NGF, NT3, and NT4/5, to C. F. Ibáñez for BDNF, mutant NGF (tri-NGF), and the p75 -/- mice, to M. V. Chao for the 9651 antiserum, to David Kaplan for the pan-Trk, TrkB, and TrkC antisera, to David Shelton at Genentech for the TrkB-IgG, and to Cephalon for CEP-1347/KT7515. I thank J. Grosman for excellent technical help and L. Greene, C. Dreyfus, and C. F. Ibáñez for valuable discussions and comments.

Correspondence should be addressed to Dr. Wilma J. Friedman, Department of Pathology, Columbia University College of Physicians and Surgeons, 630 West 168 Street, New York, NY 10032. E-mail: wjf9@columbia.edu.

Copyright (C) 2000 Society for Neuroscience $0270-6474 / 00 / 206340-07 \$ 15.00 / 0$
(Friedman et al., 1993; Arenas and Persson, 1994), and other populations. However, neurotrophins are expressed in the hippocampus from early in development (Auburger et al., 1987; Maisonpierre et al., 1990; Friedman et al., 1991, 1998; Ernfors et al., 1992) and may influence local neurons before serving as targetderived factors for afferent populations. Although p75 has not been detected in the normal adult hippocampus (Kiss et al., 1988), it is abundantly expressed during late embryonic and early postnatal development (Buck et al., 1988; Lu et al., 1989), which is the period of developmental cell death in the hippocampus (Ferrer et al., 1990; Gould et al., 1991). TrkB and TrkC receptors are also present in the hippocampus from early in development (Ernfors et al., 1992; Ringstedt et al., 1993), although TrkA has not been detected in this neuronal population (Ip et al., 1993). We investigated the possibility that neurotrophins may influence the survival or death of developing hippocampal neurons.

\section{MATERIALS AND METHODS}

Materials. NGF, NT3, NT4/5, and TrkB-IgG were generously provided by Genentech (San Francisco, CA). BDNF and the NGF triple mutant (tri-NGF) were a gift from C. F. Ibáñez (Karolinska Institute, Stockholm, Sweden). Anti-p75 IgG 192 was purchased from Chemicon (Temicula, CA), and the 9651 antiserum was generously provided by M. V. Chao (Skirball Institute, New York University). Pan-Trk, TrkB in and $\mathrm{TrkC}_{\mathrm{in} 2}$ antisera were provided by David Kaplan (Montreal Neurological Institute, Montreal, Quebec, Canada), and CEP-1347/KT7515 was from Cephalon. Eagle's MEM, Ham's F12, and penicillin-streptomycin were purchased from Life Technologies (Gaithersburg, MD). Polylysine, glucose, insulin, putrescine, progesterone, transferrin, and selenium were obtained from Sigma (St. Louis, MO). Secondary antibodies used for immunostaining were biotinylated goat anti-rabbit (Vector Laboratories, Burlingame, CA) or Alexa 488 and Alexa 594 anti-rabbit and anti-mouse antibodies from Molecular Probes (Eugene, OR) for fluorescence. The p $75-/-$ mice (Lee et al., 1992) were generously provided by C. F. Ibáñez (Karolinska Institute).

Neuronal cultures. Pregnant rats were killed by exposure to $\mathrm{CO}_{2}$ and soaked in $80 \%$ ethanol for 10 min. Embryonic day 18 (E18) rat fetuses were removed under sterile conditions and kept in PBS on ice. For experiments with mice, fetuses were removed from E16 C57BL6 wild-type or p75 - /mice (Lee et al., 1992). Hippocampi were dissected, dissociated by trituration in serum-free medium, plated on polylysine $(0.1 \mathrm{mg} / \mathrm{ml})$-coated tissue culture wells or plastic Lab-Tek slide wells, and maintained in a serum-free environment (Friedman et al., 1993; Farinelli et al., 1998). The medium consists of a 1:1 mixture of Eagle's MEM and Ham's F12 supplemented with glucose $(6 \mathrm{mg} / \mathrm{ml})$, putrescine $(60 \mu \mathrm{M})$, progesterone $(20$ $\mathrm{nM})$, transferrin $(100 \mu \mathrm{g} / \mathrm{ml})$, selenium $(30 \mathrm{nM})$, penicillin $(0.5 \mathrm{U} / \mathrm{ml})$, and streptomycin $(0.5 \mu \mathrm{g} / \mathrm{ml})$. In all experiments neurons were cultured for $4-5$ $\mathrm{d}$ before treatment. Cultures contained $<2 \%$ glial cells, confirmed by 
staining for glial markers. The absence of glia is critical because astrocytes in culture produce high levels of NGF.

Neuronal survival assay. Survival of cultured hippocampal neurons was assayed by a method we adapted (Farinelli et al., 1998; Troy et al., 2000) that has been used routinely to assess pheochromocytoma 12 (PC12) cell viability (Rukenstein et al., 1991). After removal of the medium, cultured cells were lysed, and intact nuclei were counted with a hemacytometer. Nuclei of dead cells either disintegrate or, if in the process of dying, appear pyknotic and irregularly shaped. In contrast, nuclei of healthy cells are phase bright and have clearly defined limiting membranes. Cell counts were performed in triplicate wells. Statistical significance was determined by ANOVA with Bonferroni's post hoc analysis.

Morphological analysis. Cultured cells were fixed with $4 \%$ paraformaldehyde, blocked for $1 \mathrm{hr}$ with PBS and 5\% normal goat serum, and exposed overnight at $4^{\circ} \mathrm{C}$ to primary antibody in PBS with $0.3 \%$ Triton X-100. Primary antisera were directed against p75 [9651, 1:1000 dilution (Huber and Chao, 1995), or $192 \mathrm{IgG}$ (Chemicon), 1:1000 dilution], the intracellular domain of TrkB [anti-TrkB in 1:2000 (Allendoerfer et al., 1994)], or the intracellular domain of TrkC [anti-TrkC $\mathrm{in}_{2}, 1: 1000$ (Allendoerfer et al., 1994)], indicating the presence of the full-length TrkB and TrkC receptors. Cells were then washed with PBS, exposed to the appropriate biotinylated secondary antibody, and visualized by the use of the avidin-biotinperoxidase technique (ABC Elite; Vector Laboratories). Alternatively, for double labeling, cells were visualized by the use of secondary antibodies coupled to different fluorophores (Alexa 488 and Alexa 594; Molecular Probes). Controls for all immunostaining included exposing the cells to the appropriate secondary antibodies in the absence of primary antibody. To identify dying neurons, cells were also labeled with the Hoechst 33342 dye $(1 \mu \mathrm{g} / \mathrm{ml}$; Sigma) and examined by fluorescence microscopy (Stefanis et al., 1999). Apoptotic nuclei were identified by chromatin margination or condensation and clumping.

Immunoprecipitation and Western blot analysis. Cells were lysed in a buffer consisting of Tris-buffered saline with $1 \%$ NP-40, 1 mM PMSF, 10 $\mu \mathrm{g} / \mathrm{ml}$ aprotinin, $1 \mu \mathrm{g} / \mathrm{ml}$ leupeptin, and $0.5 \mathrm{~mm}$ sodium vanadate. Total protein was quantified by the Bradford assay (Bio-Rad, Hercules, CA). For p75 immunoprecipitation, $100 \mu \mathrm{g}$ of total protein from PC12 cell or hippocampal neuron lysates was incubated with the monoclonal antibody $192 \mathrm{IgG}$ (Chemicon) for $2 \mathrm{hr}$ on a rocking platform at $4^{\circ} \mathrm{C}$. Protein A-Sepharose (Pharmacia, Piscataway, NJ) was then added to the lysates and kept for an additional $2 \mathrm{hr}$ at $4^{\circ} \mathrm{C}$. Immunoprecipitates were subjected to Western blot analysis and probed with 9651 anti-p75 antiserum (Huber and Chao, 1995). As a control, PC12 lysates were processed as described above in the absence of immunoprecipitating antibody. For analysis of tyrosine phosphorylation of trk receptors, cells were lysed as described above, incubated with wheat germ lectin-agarose (Pharmacia) for $2 \mathrm{hr}$ at $4^{\circ} \mathrm{C}$, run on a Western blot, and probed with an anti-phosphotyrosine antibody (Upstate Biotechnology, Lake Placid, NY). For Western analysis of phospho-c-Jun N-terminal kinase (P-JNK), cells were washed with PBS, harvested in SDS lysis buffer, and boiled before loading on the gel. Blots were probed with anti-P-JNK (New England Biolabs), stripped, and reprobed for JNK (New England Biolabs).

\section{RESULTS}

\section{Neurotrophins induce death of hippocampal neurons}

To assess the influence of neurotrophins on developing hippocampal neurons, primary neuronal cultures were prepared from E18 rat embryos. The p75 receptor was highly expressed in these cultured embryonic neurons and was not significantly regulated by shortterm exposure to the different neurotrophins (Fig. 1a). Expression of TrkA was not detected in hippocampal neurons, whereas TrkB and TrkC were expressed in subpopulations (Fig. 1b,c), consistent with previous observations (Ip et al., 1993). We investigated the potential influence of NGF in this population of CNS neurons that express p75 in the absence of TrkA. Hippocampal neurons were grown in culture for $5 \mathrm{~d}$ and exposed to NGF overnight. In a dose-response relationship, 1 and $10 \mathrm{ng} / \mathrm{ml} \mathrm{NGF}$ had no effect; however $100 \mathrm{ng} / \mathrm{ml} \mathrm{NGF}$ elicited a loss of $30-40 \%$ of the hippocampal neurons (Fig. $2 a$ ). The degree of neuronal death was not increased at higher doses of NGF. This dose effectiveness was consistent with binding to the $\mathrm{p} 75$ receptor. Because all neurotrophins can bind to $\mathrm{p} 75$, we examined whether other neurotrophins would elicit neuronal death in this paradigm. Surprisingly, BDNF, NT3, and NT4 also elicited a 30-40\% loss of neurons (Fig. 2a), despite the presence of TrkB and TrkC in this neuronal population (Fig. 1b,c). In a time course analysis, loss of neurons was detectable by $6 \mathrm{hr}$ after treatment and was maximal by $24 \mathrm{hr}$ (Fig. 2b). No additional neuronal loss was observed after $48 \mathrm{hr}$. a

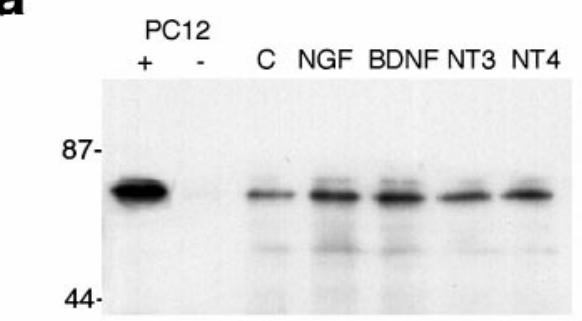

b

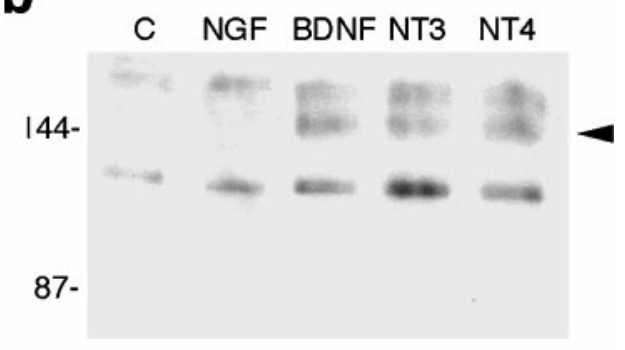

C
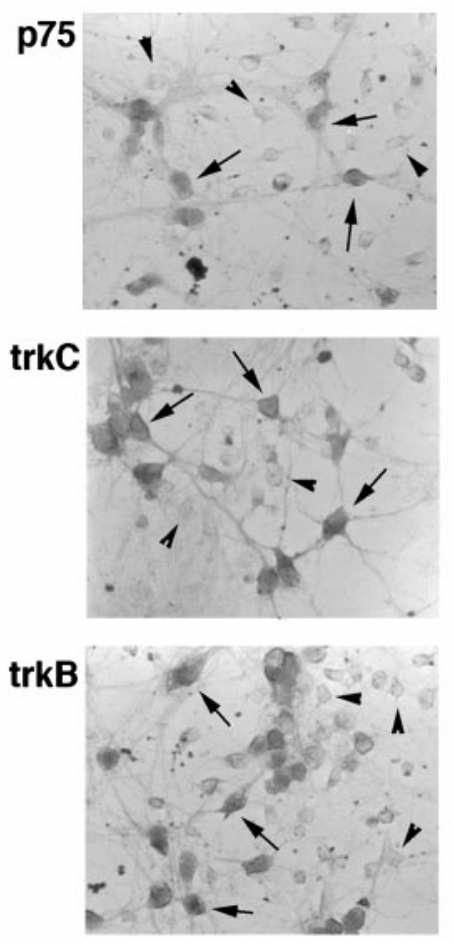

Figure 1. Expression of neurotrophin receptors in embryonic hippocampal neurons after $5 \mathrm{~d}$ in culture. $a$, Neurons were treated for $2 \mathrm{hr}$ with vehicle [control $(C)]$ or the different neurotrophins. Lysates were immunoprecipitated with anti-p75 (192 IgG), run on a Western blot, and probed with anti-p75 (9651). PC12 cell lysates were used as a positive control $(+)$. No signal was detected in PC12 lysates in the absence of the immunoprecipitating antibody $(-) . b$, Hippocampal neurons were treated for $5 \mathrm{~min}$ with vehicle $(C)$ or the different neurotrophins and analyzed for tyrosine phosphorylation of the trk proteins (arrowhead). Phosphorylation of trk receptors was induced by BDNF and NT4 and by NT3 treatment, indicating the presence of TrkB and TrkC, respectively, in the neuronal cultures (arrowhead). No TrkA phosphorylation was detected after NGF treatment. $c$, Hippocampal neurons were immunostained with antibodies against $\mathrm{p} 75$, TrkC, or TrkB. Arrows indicate positively stained neurons, and arrowheads indicate negatively stained neurons.

\section{Neurotrophin-induced death is mediated by $\mathrm{p75}$}

The dose-response relationship observed for the neurotrophins to elicit neuronal death was consistent with activation of p75. To determine the requirement for p75 binding, a mutant NGF that 
a
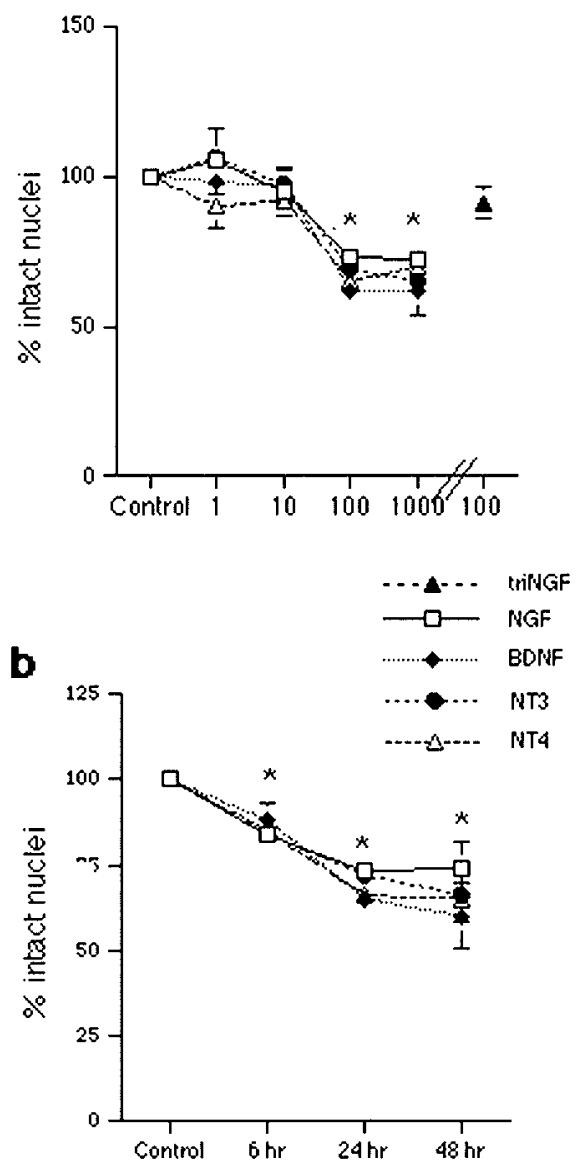

Figure 2. Neurotrophins induce the death of hippocampal neurons. Neurons were cultured for $5 \mathrm{~d}$ and treated with vehicle or neurotrophins in triplicates. Survival is reported as the percent of intact nuclei compared with that in untreated controls and is presented as the mean \pm SEM. $a$, Dose-response curve for neurotrophin-induced death of hippocampal neurons after overnight exposure to NGF, BDNF, NT3, or NT4. Data are expressed as the percent of control in triplicate samples from eight independent experiments $(n=24)$. The mutant tri-NGF that cannot bind p75 did not elicit neuronal death. An asterisk indicates values different from the control value at $p<0.001$. $b$, Time course of neurotrophin-induced death of hippocampal neurons. Neuronal loss was apparent by $6 \mathrm{hr}$ of treatment and was maximal at $24 \mathrm{hr}$. No additional cell loss was detected after longer treatment times. Data reported are from triplicate samples from three independent experiments $(n=9$ cultures per sample $)$. An asterisk indicates values different from control at $p<0.01$. The apparent absence of error bars for some samples indicates that the error was smaller than the symbol used.

lacks the ability to bind p75 (Ibáñez et al., 1992) was used and did not elicit death (Fig. 2a). This mutant NGF retains binding to TrkA and elicited neurite outgrowth from PC12 cells similar to that of wild-type NGF (data not shown). To confirm the role of p75 in mediating neurotrophin-induced death, neurons were treated with neurotrophins in the presence of a blocking antibody to p75 (9651) (Huber and Chao, 1995; Mount et al., 1998). The presence of anti-p75 prevented the death induced by NGF, BDNF, NT3, or NT4 (Fig. 3a), demonstrating that binding to p75 is required for neurotrophin-induced death of hippocampal neurons. Further confirmation of the role of $\mathrm{p} 75$ was obtained by culturing hippocampal neurons from p $75-/-$ mice (Lee et al., 1992). Neurons from these mice did not die in response to neurotrophin treatment, compared with an $\sim 40 \%$ loss of hippocampal neurons from wild-type mice (Fig. 3b).

\section{Endogenously produced neurotrophins protect via trk signaling}

BDNF, NT3, and NT4 caused a loss of hippocampal neurons despite the presence of TrkB and TrkC in this population. Previous a
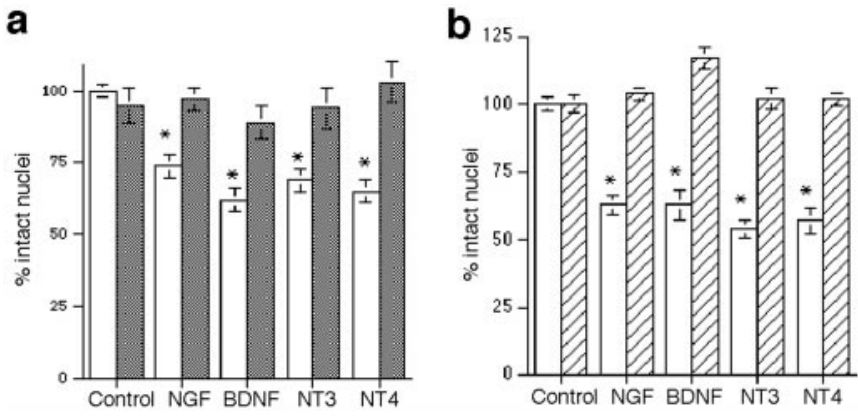

Figure 3. p75 mediates neurotrophin-induced death. $a$, Anti-p75 antiserum prevented neurotrophin-induced death of hippocampal neurons. Cultured neurons were treated overnight with neurotrophins $(100 \mathrm{ng} / \mathrm{ml})$ in the presence of normal rabbit serum (1:100 dilution; open bars) or a blocking antibody to p75 (9651; 1:100 dilution; filled bars). Data are expressed as the percent of control in triplicate samples from four independent experiments $(n=12)$. An asterisk indicates values different from control at $p<0.001$. $b$, Hippocampal neurons from $\mathrm{p} 75-/-$ mice (hatched bars) were compared with neurons from wild-type mice (open bars) for the ability of neurotrophins to induce death. Cultured neurons were treated with neurotrophins $(100 \mathrm{ng} / \mathrm{ml})$ overnight. Data are expressed as the percent of intact nuclei compared with that of untreated neurons $(n=5$ cultures per treatment), and an asterisk indicates values different from control at $p<0.001$.

studies suggested that coexpression of the cognate trk receptor abrogates a p75-mediated death signal (Davey and Davies, 1998; Yoon et al., 1998). Because the hippocampus is composed of a heterogeneous population of neurons, we investigated whether specific subpopulations of hippocampal neurons expressed p75 in the absence of TrkB or TrkC and were selectively vulnerable to death induced by neurotrophins. In untreated cultures, double labeling with anti-p75 (192 IgG) and a pan-trk antiserum revealed that $40 \%$ of the neurons that expressed p75 lacked a trk receptor. After treatment with the different factors for $6 \mathrm{hr}$, neurons were labeled with antibodies against $\mathrm{p} 75$, the cognate trk receptor (i.e., anti-TrkB $_{\text {in }}$ for BDNF- or NT4-treated neurons, anti-TrkC $\mathrm{C}_{\text {in2 }}$ for NT3-treated neurons, or a pan-Trk antibody for NGF-treated neurons), and the Hoechst 33342 dye to identify apoptotic cells by nuclear morphology. Apoptotic neurons were identified by Hoechst staining and scored for receptor phenotype (Fig. 4). Table 1 shows a comparison of the number of apoptotic neurons expressing p75 in the absence versus the presence of a trk receptor. For all neurotrophin treatments, $85-90 \%$ of the apoptotic neurons expressed p75 in the absence of a trk receptor.

Our results confirmed that expression of the cognate trk receptor primarily protected neurons from neurotrophin-induced death. In addition, despite the absence of TrkA, the majority of p75-positive neurons that were spared from NGF-induced death were labeled with the pan-Trk antibody (Table 1), indicating that these neurons expressed TrkB or TrkC. Because hippocampal neurons produce neurotrophins in culture (Friedman et al., 1998), it is possible that low concentrations of endogenously produced neurotrophins may protect neurons that express TrkB and/or TrkC from NGF-induced death. To investigate this issue, actions of endogenously produced BDNF and NT4 were prevented by the use of a TrkB-IgG fusion protein. The presence of TrkB-IgG significantly enhanced NGFinduced neuronal loss compared with NGF alone or with a control IgG, resulting in death of almost $50 \%$ of the total neuronal population (Fig. 5). When apoptotic neurons were identified by Hoechst staining and scored for receptor phenotype, the TrkB-expressing neuronal population specifically demonstrated increased vulnerability to NGF-induced death (Table 2), indicating an increased susceptibility to p75-mediated death in the absence of trk signaling. The percent of TrkC-positive neurons that were apoptotic in response to NGF was unchanged in the presence or absence of the TrkB-IgG, as expected (Table 2). Moreover, treatment with BDNF did not show enhanced neuronal death in the presence of TrkB-IgG, because neurons expressing TrkB together with p75 

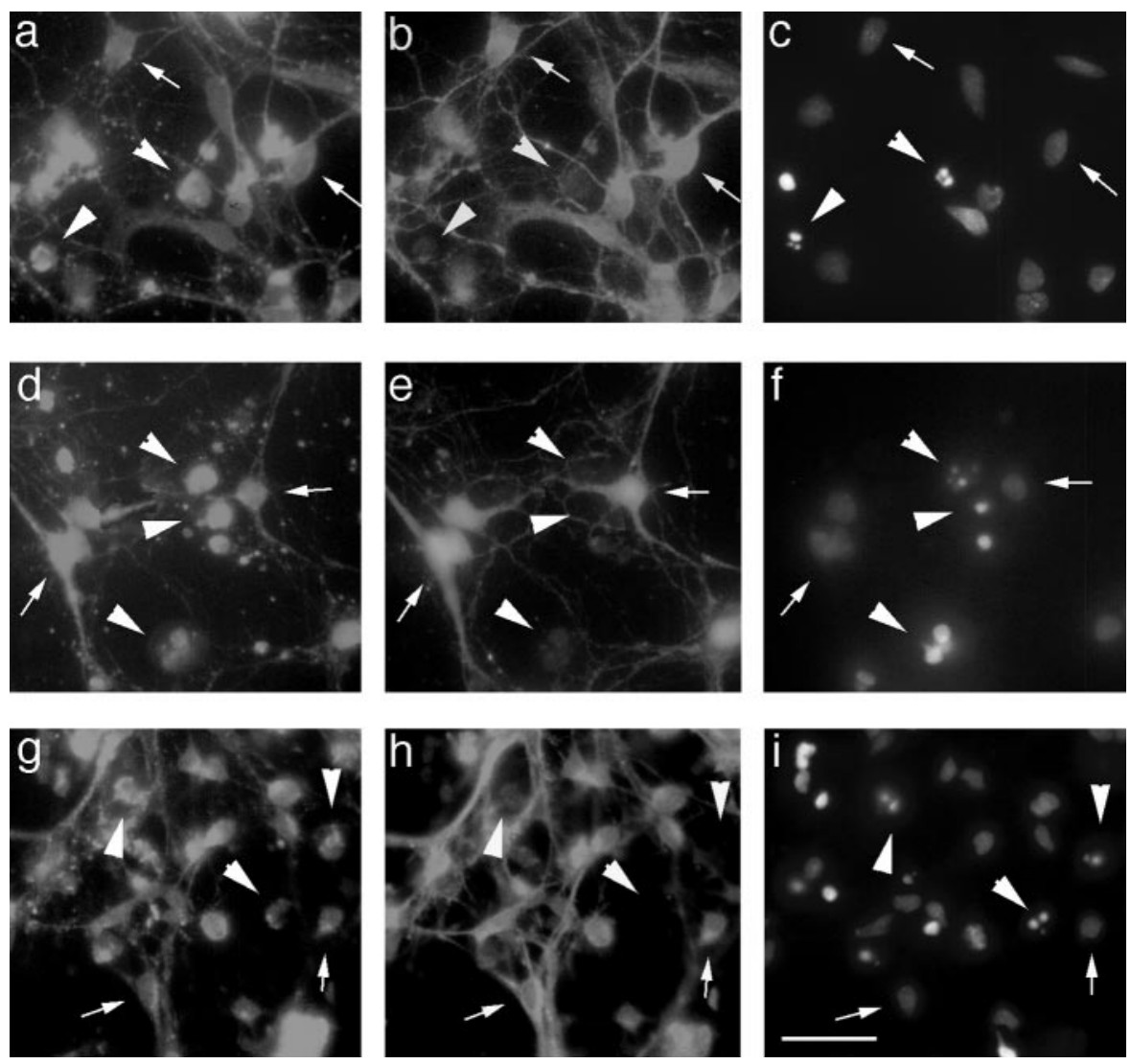

Figure 4. Neurotrophins induce apoptosis of neurons expressing p75 in the absence of trk receptors. Hippocampal neurons were treated with NGF $(a-c)$, BDNF $(d-f)$, or NT3 $(g-i)$ for $6 \mathrm{hr}$. All cultures were immunostained with anti-p75 (192 IgG; $a, d, g)$ and labeled with Hoechst $33342(c, f, i)$ to identify the nuclei of apoptotic cells. NGF-treated cultures were immunostained with anti-pan-Trk $(b)$, BDNFtreated cultures were labeled with anti-TrkB ${ }_{\text {in }}(e)$, and NT3-treated cultures were labeled with anti$\mathrm{TrkC}_{\mathrm{in} 2}(h)$. Chromatin condensation, indicative of apoptosis, was detected in neurons that expressed p75 in the absence of the relevant trk receptor (arrowheads). Healthy nuclei in neurons expressing both $\mathrm{p} 75$ and the relevant trk are indicated with arrows. Scale bar, $20 \mu \mathrm{m}$.
Table 1. Number (and percent) of apoptotic neurons expressing p75 with or without trk receptors

\begin{tabular}{llc} 
Treatment & p75+/trk- & p75+/trk + \\
\hline NGF & $63(88 \%)$ & $9(12 \%)$ \\
BDNF & $64(86 \%)$ & $10(14 \%)$ \\
NT3 & $35(88 \%)$ & $5(12 \%)$ \\
NT4 & $42(84 \%)$ & $8(16 \%)$ \\
\hline
\end{tabular}

Neurons were grown on slide wells for $5 \mathrm{~d}$ and treated with the indicated factors for 6 hr. Cultures were stained with antibodies against p75 and the appropriate trk receptor (i.e., anti-pan-Trk for NGF-treated wells, anti-TrkB ${ }_{\text {in }}$ for BDNF- and NT4treated wells, and anti-TrkC $\mathrm{in}_{2}$ for NT3-treated wells) and labeled with Hoechst 33342. Apoptotic neurons were identified by chromatin condensation in the nucleus and scored for expression of p75 and/or trk. Few apoptotic neurons were detected in control wells. Neurons were counted in eight fields per well in three independent experiments.

were still spared (Fig. 5). These data strongly support the idea that low concentrations of endogenously produced BDNF or NT4 protect TrkB-expressing neurons from p75-mediated apoptosis and that in the absence of TrkB signaling the vulnerability to NGFinduced death is increased.

\section{JNK signaling mediates neurotrophin-induced death}

Several signaling pathways have been suggested to mediate the actions of p75 in different cell types, including production of ceramide (Dobrowsky et al., 1994), activation of JNK, and induction of the nuclear factor $-\kappa \mathrm{B}(\mathrm{NF}-\kappa \mathrm{B})$ transcription factor (Yoon et al., 1998). We assessed whether either NF- $\kappa \mathrm{B}$ or JNK was activated by neurotrophins in hippocampal neurons. Electrophoretic mobility shift analysis demonstrated that NF- $\kappa \mathrm{B}$ was not activated by NGF in hippocampal neurons (data not shown). In contrast, Western blot analysis demonstrated JNK phosphorylation within $10 \mathrm{~min}$ of NGF treatment (Fig. 6a), supporting the possibility that this pathway may play a role in p75-mediated death. BDNF and NT3 treatment elicited JNK phosphorylation as well, whereas the mutant NGF that does not bind p75 (tri-NGF) (Ibáñez et al., 1992) did

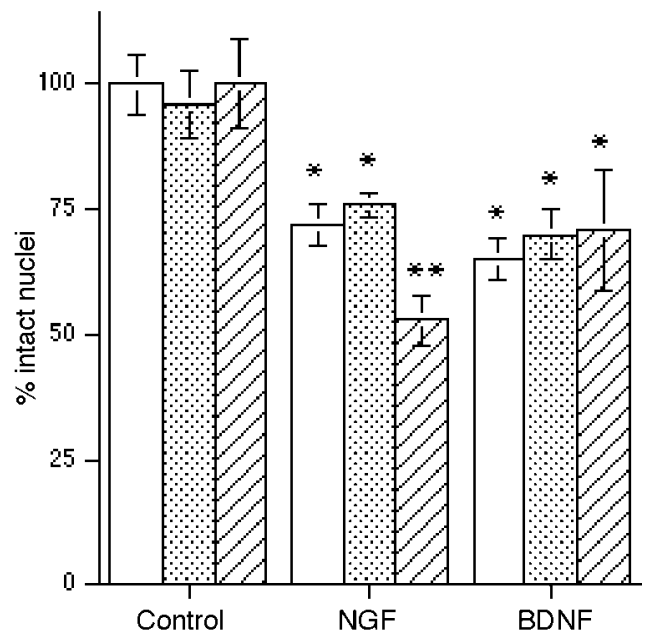

Figure 5. Blocking the actions of endogenously produced BDNF and/or NT4 with TrkB-IgG enhances neuronal loss in response to NGF. TrkBIgG $(10 \mu \mathrm{g} / \mathrm{ml})$ was added to the cells $1 \mathrm{hr}$ before the addition of neurotrophins for overnight treatment. Data are expressed as the percent of intact nuclei relative to that in the absence of added neurotrophins. Open bars indicate cells in the presence or absence of the indicated neurotrophins alone. Stippled bars show neurons with the IgG control fragment. Hatched bars indicate cells treated with TrkB-IgG. An asterisk indicates values different from control at $p<0.001$; double asterisks indicate a value different from NGF alone or the NGF + IgG control at $p<0.01$. Data reported are from triplicate samples from two independent experiments $(n=6)$.

not elicit JNK phosphorylation (Fig. 6b). Moreover, NGF-induced JNK phosphorylation was blocked by anti-p75 (Fig. $6 d$ ). To determine whether the JNK pathway plays a role in p75-mediated neuronal death, cultures were treated with CEP-1347/KT7515 to prevent upstream activation of JNK (Maroney et al., 1998). Treatment with CEP-1347/KT7515 blocked JNK phosphorylation (Fig. $6 c$ ) and prevented neurotrophin-induced death of the neurons (Fig. 


\begin{tabular}{|c|c|c|c|c|}
\hline Treatment & $\mathrm{p} 75+/ \operatorname{TrkB}-$ & $\mathrm{p} 75+/ \operatorname{TrkB}+$ & $\mathrm{p} 75+/ \operatorname{TrkC}-$ & $\mathrm{p} 75+/ \operatorname{TrkC}+$ \\
\hline $\begin{array}{c}\mathrm{NGF}+\mathrm{IgG} \\
\text { control }\end{array}$ & $24(89 \%)$ & $3(11 \%)$ & $17(89 \%)$ & $2(11 \%)$ \\
\hline $\begin{array}{l}\text { NGF + TrkB- } \\
\quad \text { IgG }\end{array}$ & $27(59 \%)$ & $19(41 \%)$ & $14(93 \%)$ & $1(7 \%)$ \\
\hline
\end{tabular}

The table indicates the number (and percent) of apoptotic neurons after $6 \mathrm{hr}$ of neurotrophin treatment expressing p 75 with or without the indicated trk receptor. Cultures were stained with antibodies against p75 and full-length TrkB or TrkC and labeled with Hoechst 33342. Apoptotic neurons were counted in eight fields per well in two independent experiments.

$6 e$ ), suggesting that the JNK pathway is essential for $\mathrm{p} 75$-mediated death of hippocampal neurons.

\section{DISCUSSION}

Recent studies have indicated that neurotrophins may elicit cell survival or cell death, depending on which receptor and signaling pathway are activated. Binding and activation of the trk family of tyrosine kinase receptors influence the survival and differentiation of numerous neuronal populations (Barde, 1994; Snider, 1994). Coexpression of p75 with trk receptors can modify neurotrophin binding (Hempstead et al., 1991; Barker and Shooter, 1994) and influence ligand discrimination (Chao, 1994), retrograde transport (Curtis et al., 1995), and signal transduction (Verdi et al., 1994). Moreover, coexpression of p75 with trk receptors can modify the survival actions of neurotrophins on peripheral sympathetic and sensory neurons (Davies et al., 1993; Barrett and Bartlett, 1994; Lee et al., 1994; Rydén et al., 1997). In contrast, when expressed in the absence of a trk receptor, the binding of NGF to p75 may elicit cell death (Rabizadeh and Bredesen, 1994; Casaccia-Bonnefil et al., 1998; Frade and Barde, 1998).

In the CNS, neurotrophin-induced cell death has been demonstrated in the developing retina (Frade et al., 1996, 1997); however the extent to which p75-mediated death may occur elsewhere in the CNS is unknown. In this study we demonstrate for the first time that all four neurotrophins can directly induce death of hippocampal neurons via the p75 receptor. Previous studies had suggested that only NGF evoked death via p75 (Carter and Lewin, 1997), although BDNF has been shown recently to elicit p75-mediated death of sympathetic neurons (Aloyz et al., 1998; Bamji et al., 1998). In these studies we show that BDNF, NT3, and NT4 as well as NGF can elicit p75-mediated death of hippocampal neurons. This was unexpected because of the presence of TrkB and TrkC in this population, because trk receptor signaling has been shown to abrogate p75-mediated death (Davey and Davies, 1998; Yoon et al., 1998). However, we found that subpopulations of neurons that were selectively vulnerable to death induced by BDNF, NT3, or NT4 expressed p75 and lacked the cognate trk receptor (TrkB or TrkC). Because TrkA was not detected in any hippocampal neurons, we anticipated that all p75-expressing neurons, including those that coexpress TrkB or TrkC, would be vulnerable to NGF treatment. Thus, a greater degree of neuronal loss was expected in response to NGF than to BDNF, NT3, or NT4. However, our experiments demonstrated the same percent of cell loss with NGF as with the other neurotrophins. The neurons spared in NGF-treated cultures were labeled with a pan-Trk antibody, suggesting that endogenously produced neurotrophins might activate trk receptors and protect the cells from $\mathrm{p} 75$-mediated death. To confirm this hypothesis, a TrkB-IgG fusion protein was used to bind endogenously produced BDNF and/or NT4, thereby preventing activation of TrkB. This treatment caused the TrkB+/p75+ population to become vulnerable to NGF-induced death, demonstrating that in the absence of TrkB stimulation these neurons were susceptible to p75-mediated death. Thus, neuronal survival or death may be controlled by a balance between signaling pathways activated by the trk or p75 receptors.

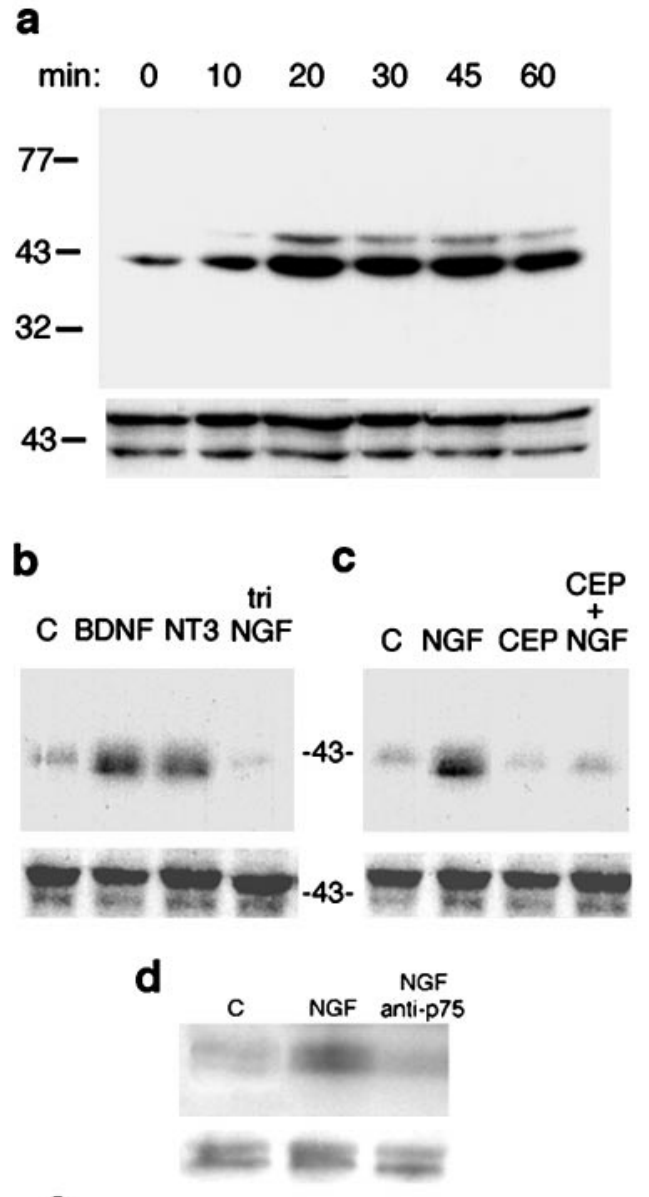

e

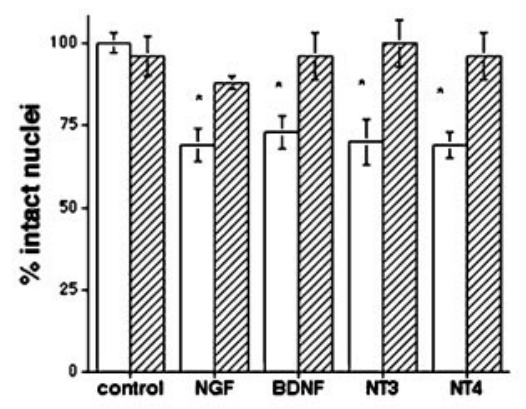

Figure 6. The JNK-signaling pathway mediates neurotrophin-induced death of hippocampal neurons. $a$, NGF induces JNK phosphorylation in hippocampal neurons. Neurons were treated with NGF $(100 \mathrm{ng} / \mathrm{ml})$ for the times indicated. $b$, JNK phosphorylation was also induced by BDNF and NT3 $(100 \mathrm{ng} / \mathrm{ml})$ treatment of hippocampal neurons, but not by mutant NGF (tri-NGF) that lacks p75 binding. Shown is a 20 min time point. $c$, Cultures were treated with NGF for $20 \mathrm{~min}$ in the presence or absence of CEP-1347/KT7515 (CEP). Incubation of cells with 200 nM CEP-1347/ KT7515 prevented JNK phosphorylation by NGF, whereas CEP-1347/ KT7515 by itself had no effect. $d$, Phosphorylation of JNK by NGF was prevented by anti-p75 (9651). Cells were pretreated for $1 \mathrm{hr}$ with anti-p75 and then exposed to NGF $(100 \mathrm{ng} / \mathrm{ml})$. A $20 \mathrm{~min}$ time point is shown. Blots shown in $a-d$ were probed for P-JNK (top panels) and stripped and reprobed for JNK (bottom panels). $e$, Prevention of JNK activation with CEP-1347/KT7515 blocked neurotrophin-induced death. Cultures were treated with neurotrophins overnight in the absence (open bars) or presence (hatched bars) of $200 \mathrm{~nm} \mathrm{CEP-1347/KT7515.} \mathrm{Data} \mathrm{are} \mathrm{expressed} \mathrm{relative} \mathrm{to}$ the control number of cells in the absence of added neurotrophins. An asterisk indicates values different from control at $p<0.01$. Data are from triplicate samples from three independent experiments $(n=9)$.

Binding of NGF to p75 has been shown to elicit production of ceramide (Dobrowsky et al., 1994), which can act as a second messenger leading to induction of NF- $\mathrm{B}$ (Schutze et al., 1992; Mathias et al., 1993) or activation of the JNK pathway (Verheij et 
al., 1996). In oligodendrocytes, NGF induced activation of both the $\mathrm{NF}-\kappa \mathrm{B}$ and JNK pathways; however it is specifically the JNK pathway that leads to cell death (Yoon et al., 1998). Activation of JNK has been implicated in a variety of other cell death paradigms as well (Xia et al., 1995; Chen et al., 1996; Park et al., 1996). In these studies, activation of NF- $\kappa \mathrm{B}$ by neurotrophins was not detected in hippocampal neurons; however JNK was phosphorylated by NGF, BDNF, and NT3. JNK phosphorylation was not induced by the mutant NGF lacking the p75-binding site and was also prevented by the anti-p75-blocking antibody, indicating that binding to $\mathrm{p} 75$ is required for neurotrophins to activate this signaling pathway. When JNK activation was blocked by the use of CEP$1347 /$ K T7515, NGF-induced neuronal death was prevented, suggesting that this pathway is essential for signaling the p75-mediated death of hippocampal neurons.

NGF has been shown to elicit production of ceramide via p75 in hippocampal neurons (Brann et al., 1999), leading to increased neurite outgrowth when provided during the first $18 \mathrm{hr}$ after plating. Ceramide has been shown to have different effects on neurons at different stages of growth and may lead to neurite growth or apoptosis (Schwarz and Futerman, 1997). Thus, NGF may also have different effects at different stages of neuronal growth, possibly mediated via ceramide production. When the neurons are initially beginning to elaborate processes, signaling via p75 apparently contributes to a growth response (Brann et al., 1999). However, in our studies NGF was provided to the neurons after $5 \mathrm{~d}$ in vitro, when the neurons had already elaborated an extensive network of neurites. An alternative possibility is that the effects observed on neurite outgrowth may represent a synergy between NGF and other glial-derived factors, because the neurons in those studies were grown in the presence of glia or glialconditioned media (Brann et al., 1999).

The p75 receptor is highly expressed in the hippocampus during the period of developmental cell death ( $\mathrm{Lu}$ et al., 1989) and is upregulated under conditions of damage (Roux et al., 1999), suggesting a possible role for this receptor in mediating neuronal death. The hippocampus is critical for learning and memory, and its function is compromised in Alzheimer's disease. Therefore defining mechanisms that contribute to the death of these neurons has important implications for hippocampal function. We suggest that the interaction of neurotrophins with p75 may be a general mechanism for normal developmental cell death and possibly for neuronal death associated with damage or disease in the CNS. Neurotrophins have been suggested to be potential therapeutic agents for neurodegenerative diseases; however the possibility that these factors may elicit death in susceptible neurons while supporting survival of other populations must be further investigated. Thus, the actions of neurotrophins in the brain represent a balance between survival- and death-promoting activities.

\section{REFERENCES}

Alderson RF, Alterman AL, Barde Y-A, Lindsay RM (1990) Brainderived neurotrophic factor increases survival and differentiated functions of rat septal cholinergic neurons in culture. Neuron 5:297-306.

Allendoerfer KL, Cabelli RJ, Escandon E, Kaplan DR, Nikolics K, Shatz CJ (1994) Regulation of neurotrophin receptors during the maturation of the mammalian visual system. J Neurosci 14:1795-1811.

Aloyz RS, Bamji SX, Pozniak CD, Toma JG, Atwal J, Kaplan DR, Miller FD (1998) P53 is essential for developmental neuron death as regulated by the trkA and p75 neurotrophin receptors. J Cell Biol 143:1691-1703.

Arenas E, Persson H (1994) Neurotrophin-3 prevents the death of adult central noradrenergic neurons in vivo. Nature 367:368-371.

Auburger G, Heumann R, Hellweg R, Korsching S, Thoenen H (1987) Developmental changes of nerve growth factor and its mRNA in the rat hippocampus: comparison with choline acetyltransferase. Dev Biol 120:322-328.

Bamji SX, Majdan M, Pozniak CD, Belliveau DJ, Aloyz R, Kohn J, Causing CG, Miller FD (1998) The p75 neurotrophin receptor mediates neuronal apoptosis and is essential for naturally occurring sympathetic neuron death. J Cell Biol 140:911-923.

Barde YA (1994) Neurotrophins: a family of proteins supporting the survival of neurons. Prog Clin Biol Res 390:45-56.

Barker PA, Shooter EM (1994) Disruption of NGF binding to the low affinity neurotrophin receptor p75LNTR reduces NGF binding to trkA on PC12 cells. Neuron 13:203-215.
Barrett GL, Bartlett P (1994) The p75 nerve growth factor receptor mediates survival or death depending on the stage of sensory neuron development. Proc Natl Acad Sci USA 91:6501-6505.

Brann AB, Scott R, Neuberger Y, Abulafia D, Boldin S, Fainzilber M, Futerman AH (1999) Ceramide signaling downstream of the p75 neurotrophin receptor mediates the effects of nerve growth factor on outgrowth of cultured hippocampal neurons. J Neurosci 19:8199-8206.

Buck CR, Martinez HJ, Chao MV, Black IB (1988) Differential expression of the nerve growth factor receptor gene in multiple brain areas. Dev Brain Res 44:259-268.

Carter BD, Lewin GR (1997) Neurotrophins live or let die: does p75 decide? Neuron 18:187-190.

Casaccia-Bonnefil P, Carter BD, Dobrowsky RT, Chao MV (1996) Death of oligodendrocytes mediated by the interaction of nerve growth factor with its receptor p75. Nature 383:716-719.

Casaccia-Bonnefil P, Kong H, Chao MV (1998) Neurotrophins: the biological paradox of survival factors eliciting apoptosis. Cell Death Differ 5:357-364.

Chao MV (1994) The p75 neurotrophin receptor. J Neurobiol 25:1373-1385.

Chen KS, Nishimura MC, Armanini MP, Crowley C, Spencer SD, Phillips HS (1997) Disruption of a single allele of the nerve growth factor gene results in atrophy of basal forebrain cholinergic neurons and memory deficits. J Neurosci 17:7288-7296.

Chen YR, Wang X, Templeton D, Davis RJ, Tan TH (1996) The role of c-Jun N-terminal kinase (JNK) in apoptosis induced by ultraviolet C and gamma radiation. Duration of JNK activation may determine cell death and proliferation. J Biol Chem 271:31929-31936.

Curtis R, Adryan KM, Stark JL, Park JS, Compton DL, Weskamp G, Huber LJ, Chao MV, Jaenisch R, Lee K-F, Lindsay RM, DiStefano PS (1995) Differential role of the low affinity neurotrophin receptor (p75) in retrograde axonal transport of the neurotrophins. Neuron 14:1201-1211.

Davey F, Davies A (1998) TrkB signalling inhibits p75-mediated apoptosis induced by NGF in embryonic proprioceptive neurons. Curr Biol 115:56-67.

Davies A, Lee K-F, Jaenisch R (1993) p75-deficient trigeminal sensory neurons have an altered response to NGF but not to other neurotrophins. Neuron 11:1-20.

Dobrowsky R, Werner M, Castellino A, Chao M, Hannun Y (1994) Activation of the sphingomyelin cycle through the low-affinity neurotrophin receptor. Science 265:1596-1599.

Ernfors P, Merlio J-P, Persson H (1992) Cells expressing mRNA for neurotrophins and their receptors during embryonic rat development. Eur J Neurosci 4:1140-1158.

Farinelli SE, Greene LA, Friedman WJ (1998) Neuroprotective actions of dipyridamole on cultured CNS neurons. J Neurosci 18:5112-5123.

Ferrer I, Serrano T, Soriano E (1990) Naturally occurring cell death in the subicular complex and hippocampus in the rat during development. Neurosci Res 8:60-66.

Frade JM, Barde YA (1998) Nerve growth factor: two receptors, multiple functions. Bioessays 20:137-145.

Frade JM, Rodriguez-Tebar A, Barde YA (1996) Induction of cell death by endogenous nerve growth factor through its p75 receptor. Nature 383:166-168.

Frade JM, Bovolenta P, Martinez-Morales JR, Arribas A, Barbas JA, Rodriguez-Tebar A (1997) Control of early cell death by BDNF in the chick retina. Development 124:3313-3320.

Friedman WJ, Ernfors P, Persson H (1991) In situ hybridization reveals both transient and persistent expression of HDNF/NT-3 mRNA in the rat brain during postnatal development. J Neurosci 11:1577-1584.

Friedman WJ, Ibanez CF, Hallbook F, Persson H, Cain LD, Dreyfus CF, Black IB (1993) Differential actions of neurotrophins in the locus coeruleus and basal forebrain. Exp Neurol 119:72-78.

Friedman WJ, Black IB, Kaplan DR (1998) Distribution of the neurotrophins brain-derived neurotrophic factor, neurotrophin-3, and neurotrophin- $4 / 5$ in the postnatal rat brain: an immunocytochemical study. Neuroscience 84:101-114.

Gould E, Woolley CS, McEwen BS (1991) Naturally occurring cell death in the developing dentate gyrus of the rat. J Comp Neurol 304:408-418.

Hefti F, Dravid A, Hartikka J (1984) Chronic intraventricular injections of nerve growth factor elevate hippocampal choline acetyltransferase activity in adult rats with partial septohippocampal lesions. Brain Res 293:305-311.

Hempstead BL, Martin-Zanca D, Kaplan DR, Chao MV (1991) High affinity NGF binding requires co-expression of the trk proto-oncogene and the low affinity NGF receptor. Nature 350:678-683.

Huber LJ, Chao MV (1995) Mesenchymal and neuronal cell expression of the p75 neurotrophin receptor are distinguished during morphogenesis of transgenic animals. Dev Biol 167:227-238.

Ibáñez CF, Ebendal T, Barbany G, Murray-Rust J, Blundell TL, Persson H (1992) Disruption of the low affinity receptor-binding site in NGF allows neuronal survival and differentiation by binding to the trk gene product. Cell 69:1-20.

Ip NY, Ibáñez CF, Nye SH, McClain J, Jones PF, Gies DR, Belluscio L, Le Beau MM, Espinosa R, Squinto SP, Persson H, Yancopoulos GD (1992) Mammalian neurotrophin-4: structure, chromosomal localization, tissue 
distribution, and receptor specificity. Proc Natl Acad Sci USA 89:3060-3064.

Ip NY, Li Y, Yancopoulos GD, Lindsay RM (1993) Cultured hippocampal neurons show responses to BDNF, NT3, and NT4, but not NGF. J Neurosci 13:3394-3405.

Kaplan DR, Hempstead B, Martin-Zanca D, Chao MV, Parada LF (1991) The trk proto-oncogene product is a receptor for nerve growth factor. Science 252:554-558.

Kiss J, McGovern J, Patel AJ (1988) Immunohistochemical localization of cells containing nerve growth factor receptors in the different regions of the adult rat forebrain. Neuroscience 27:731-748.

Klein R, Jing S, Nanduri V, O'Rourke E, Barbacid M (1991a) The trk proto-oncogene encodes a receptor for nerve growth factor. Cell 65:189-197.

Klein R, Nanduri V, Jing S, Lamballe F, Tapley P, Bryant S, Cordon-Cardo C, Jones KR, Reichardt LF, Barbacid M (1991b) The trkB tyrosine protein kinase is a receptor for brain-derived neurotrophic factor and neurotrophin-3. Cell 66:1-20.

Lamballe F, Klein R, Barbacid M (1991) trkC, a new member of the trk family of tyrosine protein kinases, is a receptor for neurotrophin-3. Cell 66:967-979.

Lee KF, Li E, Huber LJ, Landis SC, Sharpe AH, Chao MV, Jaenisch R (1992) Targeted mutation of the gene encoding the low affinity NGF receptor p75 leads to deficits in the peripheral sensory nervous system. Cell 69:737-749.

Lee KF, Davies AM, Jaenisch R (1994) p75-deficient embryonic dorsal root sensory and neonatal sympathetic neurons display a decreased sensitivity to NGF. Development 120:1027-1033.

Lu B, Buck CR, Dreyfus CF, Black IB (1989) Expression of NGF and NGF receptor mRNAs in the developing brain: evidence for local delivery and action of NGF. Exp Neurol 104:191-199.

Maisonpierre PC, Belluscio L, Friedman B, Alderson RF, Wiegand SJ, Furth ME, Lindsay RM, Yancopoulos GD (1990) NT-3, BDNF, and NGF in the developing rat nervous system: parallel as well as reciprocal patterns of expression. Neuron 5:501-509.

Maroney AC, Glicksman MA, Basma AN, Walton KM, Knight E, Murphy CA, Bartlett BA, Finn JP, Angeles T, Matsuda Y, Neff NT, Dionne CA (1998) Motoneuron apoptosis is blocked by CEP-1347 (KT 7515), a novel inhibitor of the JNK signaling pathway. J Neurosci 18:104-111.

Mathias S, Younes A, Kan C-C, Orlow I, Joseph C, Kolesnick RN (1993) Activation of the sphingomyelin signaling pathway in intact EL4 cells and in a cell-free system by Il-1B. Science 259:519-522.

Mount HT, Elkabes S, Dreyfus CF, Black IB (1998) Differential involvement of metabotropic and p75 neurotrophin receptors in effects of nerve growth factor and neurotrophin-3 on cultured Purkinje cell survival. J Neurochem 70:1045-1053.

Oppenheim RW, Yin QW, Prevette D, Yan Q (1992) Brain-derived neurotrophic factor rescues developing avian motoneurons from cell death Nature 360:755-757.
Park DS, Stefanis L, Yan CYI, Farinelli SE, Greene LA (1996) Ordering the cell death pathway. Differential effects of BCL2, an interleukin-1converting enzyme family protease inhibitor, and other survival agents on JNK activation in serum/nerve growth factor-deprived PC12 cells. J Biol Chem 271:21898-21905.

Rabizadeh S, Bredesen DE (1994) Is p75NGFR involved in developmental neural cell death? Dev Neurosci 16:207-211.

Ringstedt T, Lagercrantz H, Persson H (1993) Expression of members of the trk family in the developing postnatal rat brain. Dev Brain Res $72: 119-131$.

Roux PP, Colicos MA, Barker PA, Kennedy TE (1999) p75 neurotrophin receptor expression is induced in apoptotic neurons after seizure. J Neurosci 19:6887-6896.

Rukenstein A, Rydel RE, Greene LA (1991) Multiple agents rescue PC12 cells from serum-free cell death by translation- and transcriptionindependent mechanisms. J Neurosci 11:2552-2563.

Rydén M, Hempstead B, Ibáñez CF (1997) Differential modulation of neuron survival during development by nerve growth factor binding to the p75 neurotrophin receptor. J Biol Chem 272:16322-16328.

Schutze S, Potthof K, Machleidt T, Berkovic D, Wiegmann K, Kronke M (1992) TNF activates NF- $\kappa$ B by phosphatidylcholine-specific phospholipase C-induced "acidic" sphingomyelin breakdown. Cell 71:765-776.

Schwarz A, Futerman AH (1997) Distinct roles for ceramide and glucosylceramide at different stages of neuronal growth. J Neurosci 17:2929-2938.

Snider WD (1994) Functions of the neurotrophins during nervous system development: what the knockouts are teaching us. Cell 77:627-638.

Stefanis L, Park DS, Friedman WJ, Greene LA (1999) Caspasedependent and -independent death of camptothecin-treated embryonic cortical neurons. J Neurosci 19:6235-6247.

Troy CM, Rabacchi SA, Friedman WJ, Frappier TF, Brown K, Shelanski ML (2000) Caspase-2 mediates neuronal cell death induced by $\beta$-amyloid. J Neurosci 20:1386-1392.

Verdi JM, Birren SJ, Ibáñez CF, Persson H, Kaplan DR, Benedetti M, Chao MV, Anderson DJ (1994) p75LNGFR regulates Trk signal transduction and NGF-induced neuronal differentiation in MAH cells. Neuron $12: 733-745$.

Verheij M, Bose R, Lin XH, Yao B, Jarvis WD, Grant S, Birrer MJ, Szabo E, Zon LI, Kyriakis JM, Haimovitz-Friedman A, Fuks Z, Kolesnick RN (1996) Requirement for ceramide-initiated SAPK/JNK signalling in stress-induced apoptosis. Nature 380:75-79.

Xia Z, Dickens M, Raingeaud J, Davis RJ, Greenberg ME (1995) Opposing effects of ERK and JNK-p38 MAP kinases on apoptosis. Science 270:1326-1331.

Yan Q, Johnson Jr EM (1988) An immunohistochemical study of the nerve growth factor receptor in developing rats. J Neurosci 8:3481-3498.

Yoon SO, Casaccia-Bonnefil P, Carter B, Chao MV (1998) Competitive signaling between TrkA and p75 nerve growth factor receptors determines cell survival. J Neurosci 18:3273-3281. 